\title{
Analisis pengaruh faktor internal bank dan eksternal terhadap Non-Performing Financing (NPF) pada Bank Perkreditan Rakyat Syariah di Indonesia
}

\author{
Rindang Nuri Isnaini Nugrohowati ${ }^{*}$, Syafrildha Bimo \\ Fakultas Ekonomi, Universitas Islam Indonesia \\ *Corresponding Author e-mail: rindangnuri@uii.ac.id
}

\begin{tabular}{l} 
Keywords: \\
Non-Performing Financing, \\
BPRS, Internal Factors, \\
Macroeconomic factors. \\
\hline DOI: \\
10.20885/JEKI.vol5.iss1.art6
\end{tabular}

$\underline{10.20885 / J E K I . v o l 5 . i s s 1 . a r t 6}$

\begin{abstract}
This study aims to determine the internal and macroeconomic factors that influence NonPerforming Financing (NPF) of BPRS (Sharia Rural Banks) in Indonesia. Data analysis method used in this study is panel data regression by taking a sample of 54 BPRS from 2012 to 2017 biannually. The results of this study show that toward NPF of BPRS in Indonesia, the variable of Total Asset has no significant effect, CAR and ROA have a negative and significant effect, while OER has a positive and significant effect. Meanwhile, the macroeconomic variables of BI Rate and PDRB have a positive and significant effect toward NPF of BPRS in Indonesia. Lastly, the variables of inflation and unemployment have no effect toward NPF of BPRS in Indonesia.
\end{abstract}

\begin{abstract}
Abstrak
Penelitian ini bertujuan untuk mengetahui faktor internal dan faktor makroekonomi yang mempengaruhi Non Performing Financing (NPF) pada BPRS di Indonesia. Metode analisis data menggunakan regresi data panel dengan mengambil sampel 54 BPRS dengan periode waktu semesteran dari tahun 2012 sampai 2017. Hasil dari penelitian ini adalah variabel Total Asset tidak berpengaruh signifikan terhadap NPF pada BPRS di Indonesia. Variabel CAR dan ROA memiliki pengaruh negatif dan signifikan terhadap NPF pada BPRS di Indonesia. Variabel BOPO memiliki pengaruh positif dan signifikan terhadap NPF pada BPRS di Indonesia. Sementara itu variable makro ekonomi BI Rate dan PDRB memiliki pengaruh positif dan signifikan terhadap NPF pada BPRS di Indonesia. Sementara variabel Inflasi dan pengangguran tidak memiliki pengaruh terhadap NPF pada BPRS di Indonesia.
\end{abstract}

\section{Pendahuluan}

Dalam skala mikro keberadaan Bank Perkreditan Rakyat Syariah (BPRS) memiliki peran penting dalam menggerakkan perekonomian disektor riil, hal ini tidak terlepas dari peran BPRS dalam meningkatkan pertumbuhan Unit Usaha Kecil Menengah (UMKM) yang merupakan obyek pembiayaan BPRS. Sampai dengan Desember 2018 Bank Perkreditan Rakyat Syariah memiliki jaringan kantor sebanyak 167 yang hampir tersebar di seluruh penjuru nusantara. Total aset BPRS selama tahun 2013 sampai 2018 mengalami peningkatan sebesar $111.909 \%$ menjadi Rp12.361,734 triliun atau meningkat $18.65 \%$ setiap tahunnya. Pada periode yang sama peningkatan aset BPRS juga diikuti oleh peningkatan Dana Pihak Ketiga (DPK) dan pembiayaan yang meningkat masing-masing $71,008 \%$ dan $51,837 \%$ atau meningkat $11,834 \%$ dan $8,639 \%$ setiap tahunnya (Otoritas Jasa Keuangan, 2017).

Pada perkembangan saat ini BPRS memiliki tantangan yang besar yaitu tingkat persaingan yang tinggi dan kemampuan pengedalian risiko terutama risiko kredit. Risiko kredit adalah risiko akibat kegagalan nasabah atau pihak lain dalam memenuhi kewajiban kepada Bank sesuai dengan perjanjian yang disepakati. Sejauh ini risiko kredit dikenal sebagai risiko terbesar yang dihadapi bank. Risiko ini tidak terhindarkan karena risiko tersebut melekat pada kegiatan utama yang dijalankan bank yaitu menyalurkan dana. Risiko ini menjadi risiko terbesar karena kerugian akibat kredit macet dapat berpotensi menghancurkan permodalan bank. Rasio kredit bermasalah atau Non-Performing Financing (NPF) merupakan rasio yang yang digunakan untuk mengukur kredit macet suatu bank.

Dalam perbankan syariah pembiayaan merupakan kegiatan utama bank dalam mendapatkan pendapatan. Semakin besar pembiayaan dibandingkan dengan deposit atau simpanan masyarakat pada suatu perbankan maka resiko yang ditanggung perbankan tersebut juga semakin besar, salah satu resiko yang ditanggung perbankan itu sendiri ialah pembiayaan bermasalah atau biasa disebut Non-Performing Financing (NPF) pada perbankan syariah. NPF dalam perbankan konvesional dikenal dengan Non-Performing Loan (NPL) yang merupakan salah satu dari sekian banyaknya indikator untuk melihat kinerja sebuah perbankan. 
Tingginya nilai NPF/NPL menunjukan indikator gagalnya perbankan tersebut dalam mengelola dana yang disalurkan pada masyarakat untuk usaha yang dapat mempengaruhi kinerja perbankan itu sendiri. Dilihat dari banyaknya masalah yang bisa muncul apabila nilai rasio NPF tinggi maka sangatlah penting bagi sebuah perbankan untuk rasio NPF memenuhi rasio NPF sesuai dengan ketentuan dari regulator. Otoritas Jasa Keuangan (OJK) selaku badan pemerintah yang memiliki tugas mengatur dan mengawasi jasa keuangan akan memanggil setiap bank yang memiliki rasio NPF yang tinggi. Hal tersebut dilakukan guna untuk menjaga rasio NPF setiap bank tidak melebihi $5 \%$.

Secara nasional hingga Desember 2018 rasio BPRS masih terbilang tingi yaitu sebesar 9,30\% rasio ini turun bulan sebelumnya yang mencapai $10.94 \%$. Berikut ini merupakan grafik pertumbuhan rasio NPF pada beberapa BPRS pada 3 wilayah di Indonesia pada tahun $2012-2017$.

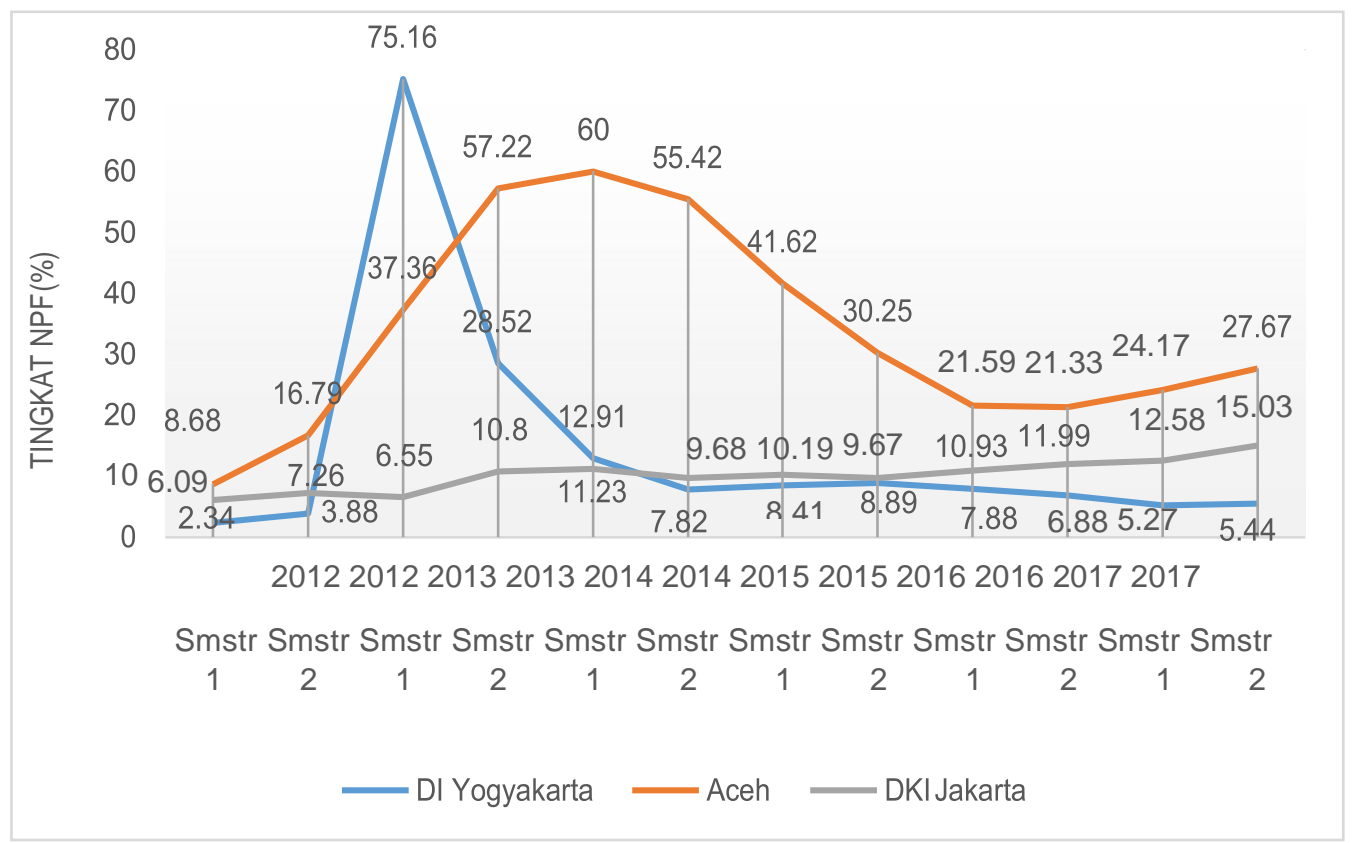

Sumber: Badan Pusat Statistik, 2018 (data diolah)

Grafik 1. Grafik NPF pada 3 BPRS di Indonesia pada tahun 2012 - 2017

Tingkat rasio NPF di tiga BPRS yang ada di wilayah Yogyakarta, Aceh dan DKI Jakarta menunjukkan nilai yang berfluktuatif dengan nilai yang cukup tinggi. Nilai NPF mencapai nilai tertinggi sebesar 75,16\% dialami oleh salah satu BPRS di Yogyakarta pada periode semester pertama tahun 2012, namun pada tahun 2014 nilai tersebut menurun tajam menjadi $12,91 \%$. Banyak faktor yang turut menetukan rasio NPF baik yang berasal dari faktor internal maupun eksternal. Faktor-faktor mikro atau spesifik yang berkaitan dengan manajemen bank merupakan determinan internal, sementara determinan eksternal adalah variabel yang tidak berkaitan dengan manajemen bank tetapi mencerminkan lingkungan ekonomi yang turut mempengaruhi operasi dan kinerja perbankan.

Dari grafik 1 menunjukkan rasio NPF BPRS di tiga wilayah menunjukkan tren yang berbeda. Salah satu BPRS di DKI Jakarta menunjukkan nilai NPF yang relative stabil, namun di Aceh menunjukkan pergerakan yang berbeda. Salah satu BPRS di Aceh menunjukkan bahwa pada periode 2012 rasio NPF memiliki tren yang meningkat namun mulai periode 2014 memiliki kecenderungan yang semakin menurun. Melihat pergerakan tersebut maka menarik untuk dilakukan penelitian dengan mengidentifikasi factor-faktor apa yang turut mempengaruhi nilai NPF di Bank Perkreditan Syariah.

Sampai saat ini penelitian mengenai determinan dari NPF banyak dilakukan diberbagai Negara mengingat rasio NPF merupakan ukuran dari kemampuan bank dalam memanajemen risiko kredit. Negara (2012) melakukan penelitian dengan mengambil studi kasus bank di Ethiopian. Temuan dari penelitian ini menunjukkan bahwa penilaian kredit yang buruk, kegagalan pemantauan pinjaman, budaya kredit yang kurang berkembang, syarat dan ketentuan kredit yang lunak, pinjaman yang agresif, integritas yang lemah, kapasitas kelembagaan yang lemah, persaingan yang tidak adil antar bank merupakan penyebab adanya gagal bayar kredit. Namun, hasil penelitian gagal mendukung adanya hubungan antara ukuran bank, tingkat bunga yang mereka tetapkan terhadap kredit macet. Penelitian lain dilakukan oleh Mutamimah \& Chasanah (2012) yang menganalisis factor internal dan 
eksternal yang mempengaruhi NPF Bank Umum Syariah di Indonesia. Hasil penelitiannya menunjukkan bahwa GDP riil dan kurs tidak berpengaruh signifikan terhadap NPF sedangkan inflasi, rasio alokasi pembiayaan murabahah terhadap alokasi pembiayaan profit loss sharing berpengaruh signifikan negative terhadap NPF.

Joseph et al. (2012) mengungkapkan bahwa faktor eksternal lebih lazim dalam menyebabkan kredit macet bank di Zimbabwe. (Umar \& Sun, 2018) melihat faktor-faktor yang mempengaruhi NPL bank di Cina dan hasilnya menunjukkan bahwa tingkat pertumbuhan produk domestik bruto (PDB), tingkat bunga efektif, tingkat inflasi, nilai tukar mata uang asing, jenis bank, perilaku pengambilan risiko bank, konsentrasi kepemilikan, leverage dan kualitas kredit adalah penentu NPL yang signifikan di bank-bank Cina. Sementara itu Kusmayadi, Firmansyah, \& Badruzaman (2017) membandingkan faktor yang mempengaruhi NPF dan NPL di bank syariah dan bank konvensional di Indonesia. Hasilnya menunjukkan bahwa variabel SBIS, inflasi dan PDB berpengaruh signifikan negatif terhadap NPF bank syariah. Sedangkan di bank konvensional hanya PDB yang berpengaruh signifikan terhadap NPL.

Berdasarkan beberapa hasil penelitian terdahulu seperti yang diungkapkan di atas, masih perlu dilakukan penelitian kembali mengenai faktor-faktor yang mempengaruhi NPF khususnya untuk BPRS, mengingat BPRS memiliki peran penting bagi pengembangan UMKM. Penelitian ini bertujuan untuk menganalisis factor-faktor yang mempengaruhi NPF khususnya untuk BPRS di Indonesia. Panelitian ini ingin menjawab apakah faktor internal bank berupa ukuran bank, rasio Kewajiban Penyediaan Modal Minimum (KPMM), rasio CAR, BOPO dan ROA berpengaruh signifikan terhadap NPF. Disamping itu juga ingin melihat apakah variabel makro yaitu PDRB, BI Rate, Tingkat Inflasi dan pengangguran juga mempengaruhi NPF BPRS di Indonesia.

\section{Metode Penelitian}

Metode analisis dalam penelitian ini adalah data panel dengan pengolahan data menggunakan eviews 9. Jenis data yang digunakan dalam penelitian ini merupakan data sekunder dalam bentuk panel data yaitu gabungan antara data kerat lintang BPRS Syariah dan deret waktu semesteran periode 2012 sampai 2015. Data penelitian ini diperoleh dari laporan keuangan yang dipublikasikan oleh Bank Indonesia dan Otoritas Jasa Keuangan (OJK). Sampel yang digunakan adalah 54 BPRS yang ada di Indonesia. Analisis data menggunakan metode ordinary least squared, dengan fungsi rasio NPF $=\mathrm{f}$ (Total asset, $\mathrm{CAR}, \mathrm{BOPO}, \mathrm{ROA}, \mathrm{BI}$ rate, PDRB, inflasi, pengangguran $)$, sehingga menghasilkan persamaan regresi yaitu sebagai berikut:

$$
\text { Yit }=\beta_{0}+\beta_{1} X_{1}+\beta_{2} X_{2}+\beta_{3} X_{3}+\beta_{4} X_{4}+\beta_{5} X_{5}+\beta_{6} X_{6}+\beta_{7} X_{7}+\beta_{8} X_{8}+e
$$

Estimasi regresi data panel dalam penelitian ini menggunakan beberapa model, yaitu common effect model, pendekatan ini tanpa memperhatikan individu ataupun waktu. Dengan diasumsikan perilaku data untuk semua perbankan adalah sama dalam kurun waktu. Kemudian, fixed effect model, model ini mengamsusikan adanya intersep dalam persamaan dengan intersep antar variabel berbeda namun slope tetap sama. Dan, random effect models model ini akan mengestimasi data panel yang mana variabel gangguan kemungkinan akan berhubungan antar waktu dan individu.

Model terbaik yang dapat ditentukan antara common effect model, fixed effect model dan random effect model dengan menggunakan estimasi uji yaitu uji Chow test, uji Hausman dan uji Langrange Multiplier. Uji Chow dilakukan untuk menentukan model terbaik antara common effect model atau fixed effect Model sebagai pengujian yang tepat digunakan dalam estimasi data panel. Uji Hausman digunakan untuk menentukan manakah yang lebih baik digunakan antara common effect atau fixed effect untuk mengestimasi data dengan hipotesis. Uji Langrange multiplier merupakan pengujian analisis dengan tujuan menentukan metode terbaik dalam regresi data panel, apakah nantinya akan menggunakan common effect atau random effect. Uji Lagrange Multiplier dengan menggunakan eviews harus dilakukan apabila kita berada pada dua kondisi saat melakukan regresi data panel.

\section{Hasil dan Pembahasan}

Pada pembahasan ini akan ditampilkan hasil pengujian factor-faktor yang mempengaruhi kredit macet yang diukur dengan NPF pada BPRS di Indonesia. Tahap pertama yang dilakukan adalah pengujian model. Untuk pemilihan model antara common effect atau fixed effect dapat dilihat melalui p-value signifikan (kurang dari a $=5 \%$ ) maka dari itu model yang digunakan yaitu fixed effect, sebaliknya apabila p-value (lebih besar dari a= 5\%) maka model yang baik untuk digunakan adalah common effect. Kemudian dilanjutkan dengan uji Hausman untuk pemilihan antara model random effect dan fixed effect dapat dilakukan dengan melihat p-value signifikan (kurang dari a = $5 \%$ ) model yang digunakan adalah estimasi fixed effect, begitu juga sebaliknya jika p-value (lebih besar dari a= $5 \%$ ) model estimasi yang digunakan adalah random effect. Berdasarkan hasil pengujian yaitu uji Chow dan Hausman diperoleh model yang paling baik yaitu model fixed effect dengan hasil sebagai berikut: 
Tabel 2. Hasil Estimasi Regrasi Data Panel

\begin{tabular}{lrrrr}
\hline \multicolumn{1}{c}{ Variable } & Coefficient & Std. Error & t-Statistic & Prob. \\
\hline BIR & 0.541608 & 0.309056 & 1.752460 & 0.0802 \\
BOPO & 4.174899 & 0.803297 & 5.197207 & 0.0000 \\
ROA & -0.088419 & 0.025626 & -3.450384 & 0.0006 \\
TA & $-1.54 \mathrm{E}-08$ & $9.21 \mathrm{E}-09$ & -1.668231 & 0.0958 \\
KPMM & -0.021304 & 0.011274 & -1.889703 & 0.0593 \\
GDP & 0.000102 & $2.07 \mathrm{E}-05$ & 4.927205 & 0.0000 \\
INFL & -0.039105 & 0.209691 & -0.186487 & 0.8521 \\
UNEMPL & -0.135724 & 0.544825 & -0.249114 & 0.8034 \\
C & -9.701322 & 6.117954 & -1.585713 & 0.1133 \\
\hline Cross-section fixed (dummy variables) & & & \\
\hline R-squared & 0.520837 & Mean dependent var & & 11.76741 \\
Adjusted R-squared & 0.470958 & S.D. dependent var & & 11.66765 \\
F-statistic & 10.44205 & Durbin-Watson stat & & 0.789192 \\
Prob(F-statistic) & 0.000000 & & \\
\hline
\end{tabular}

Berdasarkan hasil regresi menggunakan model fixed effect diketahui nilai dari $\mathrm{R}^{2}$ sebesar 0.520923 , yang berarti bahwa sebesar 52,09\% varian dari variabel independen mampu menjelaskan varian dari variabel dependen dan sisanya dijelaskan oleh faktor lain diluar model. Sementara itu jika dilihat konstanta masing-masing BPRS dari tahun 2012-2017 dapat dilihat bahwa PT BPRS Carana Kiat Andalas memiliki nilai rasio NPF tertinggi sementara PT BPRS Amanah Ummah memiliki rasio NPF paling rendah.

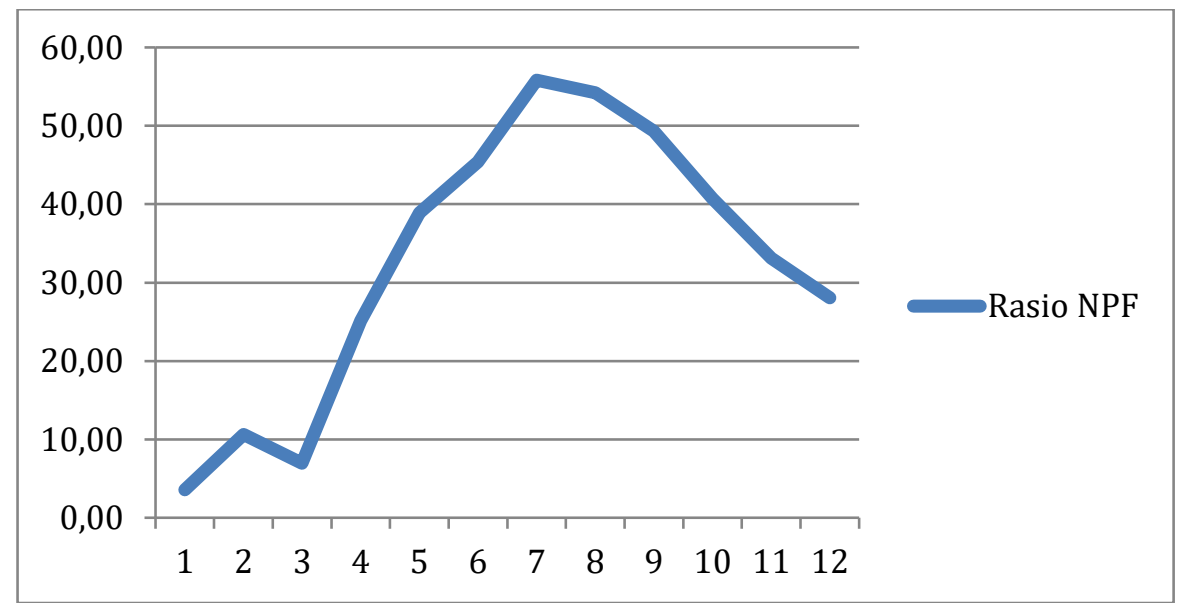

Sumber: Data Diolah

Grafik 2. Rasio NPF PT BPRS Carana Kiat Andalas

Nilai NPF PT BPRS Carana Kiat Andalas mencapai nilai tertinggi sebesar 55,82\% pada periode semester pertama tahun 2015. Sementara itu nilai terendah rasio NPF PT BPRS Carana Kiat Andalas sebesar 6,94\%. Rasio ini sangat tinggi mengingat kewajiban rasio NPF dari regulator maksimum 5\%. Tantangan besar dihadapi oleh BPRS salah satunya persaingan dengan bank umum mulai dari permodalan dan belum mampunya mencapai skala ekonomi dan kinerja yang buruk tercermin dari tingginya rasio NPF dan BOPO. Terlebih adanya kebijakan dari Bank Indonesia melalui PBI No. 14/22/PBI/2012, Bank Indonesia mewajibkan setiap Bank Umum untuk menyalurkan kredit atau pembiayaan UMKM paling rendah $20 \%$ dari total kredit atau pembiayaan yang disalurkan.

Hal ini menjadikan tingkat persaingan yang dihadapi lembaga mikro syariah semakin ketat karena adanya kewajiban kredit UMKM oleh bank umum dari pemerintah. Dengan keadaan tersebut BPRS dituntut mampu meningkatkan daya saing sehingga nasabah kepercayaan nasabah semakin bertambah. Karena ketika nasabah semakin banyak yang menggunakan jasa bank umum terutama dalam mengajukan pembiayaan maka BPRS akan berusaha menarik nasabah dengan cara mempermudah prosedur pemberian kredit. Jika demikian yang dilakukan maka tingginya risiko kredit macet tidak bisa terhindarkan karena kehati-hatian bank yang semakin berkurang. 


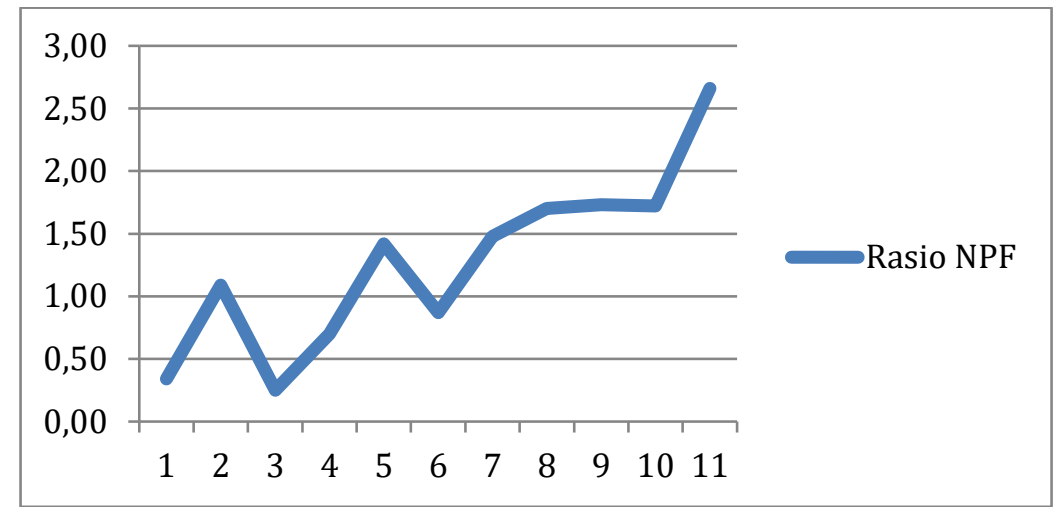

Sumber: Data Diolah

Grafik 2. Rasio NPF PT BPRS Amanah Ummah

Berbeda dengan kasus di PT BPRS Amanah Ummah yang memiliki rasio NPF terendah dibandingkan dengan 53 BPRS lainnya. Rasio NPF terendah di PT BPRS Amanah Ummah terjadi pada periode semester pertama tahun 2013 dengan nilai sebesar $0,25 \%$, sedangkan nilai tertinggi terjadi di periode kedua tahun 2017 senilai 3,31\%. Rasio ini sudah memenuhi peraturan dari bank sentral yaitu dibawah 5\%. Kemampuan BPRS dalam mengendalikan risiko terutama risiko kredit berbeda-beda di berbagai wilayah. Hal ini dikarenakan BPRS memiliki karakteristik yang berbeda dengan bank umum yaitu kegiatan operasionalnya terbatas pada suatu wilayah. Dengan demikian kinerja suatu BPRS secara tidak langsung ditentukan oleh kondisi suatu wilayah, misalnya bagaimana tingkat persaingan dan kondisi ekonomi suatu daerah.

\section{Uji Signifikansi Simultan (Uji F)}

Berdasarkan uji signifikansi simultan (Uji F) menunjukkan nilai F-Statistik sebesar 8.181596 dengan nilai probabilitas sebesar $0.000000<0,05$ (alpha) maka dapat ditarik kesimpulan dalam penelitian ini variabel Total Asset, CAR, BOPO, ROA, BI rate, PDRB, Inflasi dan Tingkat pengangguran secara bersama-sama berpengaruh signifikan terhadap NPF pada BPRS di Indonesia.

\section{Uji Signifikansi Parameter Individu (Uji t)}

Tabel 3. Hasil regresi Pengujian Hipotesis

\begin{tabular}{lcccl}
\hline Variabel & Koefisien & Probabilitas & Alpha & Keterangan \\
\hline Total Asset & $-1.54 \mathrm{E}-08$ & 0.0958 & 0,05 & Tidak Signifikan \\
CAR /KPMM & -0.021304 & 0.0593 & 0,10 & Signifikan \\
BOPO & 4.174899 & 0.0000 & 0,05 & Signifikan \\
ROA & -0.088419 & 0.0006 & 0,05 & Signifikan \\
BI Rate & 0.541608 & 0.0802 & 0,10 & Signifikan \\
PDRB & 0.000102 & 0.0000 & 0,05 & Signifikan \\
Inflasi & -0.135724 & 0.8521 & 0,05 & Tidak Signifikan \\
Tingkat Pengangguran & -0.979357 & 0.8034 & 0,05 & Tidak Signifikan \\
\hline
\end{tabular}

Dari hasil regresi tersebut maka dapat di interpretasikan bahwa BI Rate sebesar 0.541 yang artinya apabila BI Rate meningkat sebesar 1\% maka akan meningkatkan NPF sebesar 0.541. Nilai BOPO sebesar 4.174 yang artinya apabila BOPO meningkat sebesar 1\% maka akan meningkatkan NPF sebesar 4.174. Nilai ROA sebesar0.00884 yang artinya apabila ROA meningkat sebesar $1 \%$ maka akan menurunkan NPF sebesar -0.00884 . Nilai total asset yaitu -1.54E-08 yang artinya apabila total asset meningkat sebesar $1 \%$ maka akan menurunkan NPF sebesar -1.54E-08. Nilai KPMM yaitu -0.0213 yang artinya apabila KPMM meningkat sebesar $1 \%$ maka akan menurunkan NPF sebesar -0.0213. Nilai PDRB sebesar 0.000102 yang artinya apabila GDP meningkat sebesar 1 juta rupiah maka akan meningkatkan NPF sebesar 0.000102. Nilai Inflasi sebesar -0.03910 yang artinya apabila inflasi meningkat sebesar $1 \%$ maka akan menurunkan NPF sebesar -0.03910 .

\section{Pengaruh Faktor Internal Bank Terhadap Rasio Non-Performing Financing (NPF)}

Banyak faktor yang turut menentukan tingkat rasio NPF suatu bank seperti faktor internal bank berupa indikator keuangan. Indikator keuangan pertama yang akan dilihat pengaruhnya terhadap NPF adalah total aset yang 
mengindikasikan ukuran bank. Total asset yang ada pada perbankan menggambarkan strategi dan kegiatan manajemen perbankan yang berhubungan dengan pengelolaan dana bank seperti penggunaan dana untuk penyediaa kas, rekening pada bank sentral, pinjaman jangka panjang maupun pendek serta aktiva tetap perbankan itu sendiri. Dengan derajat keyakinan sebesar 5\% hasil pengujian menunjukkan bahwa ukuran bank yang diproksikan dengan total aset tidak berpengaruh signifikan terhadap NPF. Hasil ini sesuai dengan penelitian yang dilakukan oleh Firmansyah (2014) dan Negara (2012). Temuannya menunjukkan bahwa penilaian kredit yang buruk, kegagalan pemantauan pinjaman, budaya kredit yang kurang berkembang, syarat dan ketentuan kredit yang lunak, pinjaman yang agresif, integritas yang lemah, kapasitas kelembagaan yang lemah, persaingan yang tidak adil antar bank yang lebih dominan menetukan kredit bermasalah bank di Ethiopian Banks (Negara, 2012). Dengan demikian dapat dikatakan bahwa kualitas pembiayaan suatu bank tidak ditentukan oleh besar kecilnya ukuran bank, namun kemampuan pengelolaan risiko atau manajemen risiko khususnya risiko kredit jauh lebih penting.

Pengaruh KPMM terhadap NPF ditunjukkan oleh nilai koefisien -0.0213 yang artinya apabila KPMM meningkat sebesar 1\% maka akan menurunkan NPF sebesar -0.0213. Dari hasil pengujian diperoleh dnilai probabilitas sebesar 0.0593 lebih besar dari alfa 5\% namun lebih kecil dari alfa 10\%, yang berarti dengan drajat keyakinan 10\% KPMM berpengaruh signifikan negatif terhadap NPF BPRS di Indonesia. Hal ini membuktikan bahwa modal memiliki peran penting dalam menyerap risiko khususnya risiko kredit. Ketika permodalan kuat maka kemampuan bank dalam menyerap risiko juga semakin baik. Maka dari itu apabila rasio CAR pada BPRS semakin tinggi itu artinya kemampuannya dalam mengelola dananya sangat baik, sehingga akan menurunkan rasio pembiayaan bermasalah pada BPRS tersebut. Dari kegiatan operasional bank tidak semua jasa yang dilakukan bank mendapatkan hasil sesuai yang diharapkan. Sebagai contoh jika ada kreditur yang status pinjamannya tidak lancar maka hal itu akan menghambat kegiatan operasional bank dan dapat menimbulkan risiko kerugian bagi pihak bank.

Dalam hal ini modal bank berperan untuk menyangga risiko tersebut. Modal bank dapat digunakan untuk menutupi tingkat pengembalian yang tidak sesuai harapan dengan tetap bisa melanjutkan kegiatan operasinya. Karena begitu pentingnya peran modal maka banyak regulasi tentang permodalan bank, mulai dari modal awal dalam pendirian bank sampai kewajiban modal minimum yang harus dimiliki bank. Regulasi tersebut ditujukan agar perbankan dapat mengelola permodalannya dengan baik. Yaitu kondisi dimana bank dapat beroperasi sebagaimana mestinya dengan mempertahankan permodalan tetap kuat. Dengan demikian kepercayaan masyarakat terhadap perbankan tetap terjaga. Dalam kasus BPR dan BPRS regulasi penyediaan modal disetor dalam rangka pendirian BPRS disesuaikan dengan zona wilayah sebagaimana dalam peraturan Otoritas Jasa Keuangan (POJK) Nomor 20.POJK.03/2014. Hal ini mengingat BPRS memiliki karakteristik yang berbeda jika dibandingkan dengan bank umum. Ruang gerak BPRS terbatas pada satu provinsi hal ini menyebabkan kinerjanya ditentukan oleh karakteristik wilayah masing-masing. Hubungan negatif antara KPMM dan NPF sejalan dengan hasil penelitian yang dilakukan oleh Asnaini (2014) yang menyebutkan bahwa KPMM atau CAR memiliki pengaruh negatif dan signifikan terhadap pembiayaan bermasalah pada perbankan syariah. Hasil yang sama juga ditunjukkan oleh penelitan yang dilakukan oleh Firdaus (2015) yang hasil penelitiannya menunjukka bahwa CAR juga memiliki pengaruh negatif dan signifkan terhadap NPF.

Berdasarkan hasil pengolahan data, BOPO berpengaruh positif terhadap NPF dengan nilai koefisien sebesar 4.174 yang artinya apabila BOPO meningkat sebesar 1\% maka akan meningkatkan NPF sebesar 4.174. Upaya BPRS dalam menekan biaya operasionalnya dan menambah pendapatan operasionalnya akan menghasilkan rasio BOPO yang kecil sehingga hal tersebut juga akan menurunkan tingkat pembiayaan yang ada pada BPRS. Dimana pada saat BPRS memiliki pendapatan yang banyak, maka itu berarti tingkat kredit macet sangatlah rendah. Hal ini sesuai dengan penelitian yang dilakukan oleh Effendi et al. (2017) yang penelitiannya juga mengungkapkan bahwa BOPO berpengaruh positif signifikan. BOPO merupakan salah satu indikator tingkat efisiensi bank yaitu dengan membandingkan antara Biaya Operasional terhadap Pendapatan Operasional (BOPO). Perbankan dapat dikatakan efisien apabila rasio BOPO mengalami penurunan. Bank yang semakin efisien dapat diartikan bahwa kemampuannya mengelola input untuk menghasilkan output semakin baik. Pengelolaan tersebut termasuk didalamnya adalah manajemen risiko kredit, sehingga bank efisien akan mampu memanfaatkan input untuk menghasilkan output yang maksimum. Untuk mendapatkan output yang maksimum tidak mungkin dapat terjadi jika pengelolaan risiko kreditnya buruk.

Sementara itu variabel ROA berpengaruh negatif terhadap NPF pada BPRS di Indonesia. ROA ialah rasio untuk mengukur kemampuan sebuah bank dalam memperoleh keuntungan seacara keseluruhan, dimana keuntungan yang diperoleh tersebut akan meningkatkan kinerja perbankan itu sendiri. Apabila rasio ROA positif itu artinya bahwa Asset perbankan yang digunakan untuk pembiayaan memberikan keuntungan pada bank tersebut dan sebaliknya jika rasio ROA negatif maka itu artinya bahwa Asset yang digunakan perbankan tidak memberikan keuntungan bagi bank tersebut. Peningkatan rasio ROA tentunya akan menurunkan rasio pembiayaan bermasalah yang ada pada BPRS, karena dengan tingginya rasio ROA maka itu artinya keuntungan yang diperoleh oleh bank juga semakin tinggi. Ketika keuntungan yang diperoleh tinggi maka pembiayan bermasalah seperti kredit macet 
juga akan kecil. Hal ini sesuai dengan penelitian yang dilakukan oleh (Effendi et al., 2017) dan (Sholihatun \& Sriyana, 2014). Rasio ROA merupakan rasio untuk mengukur kemampuan sebuah bank dalam memperoleh keuntungan maka tingginya rasio ROA menunjukkan pembiayaan cenderung lancar, dan kemampuan nasabah dalam membayar kewajibannya juga cenderung lebih lebih baik ketika rasio ROA tinggi.

\section{Pengaruh Faktor Eksternal Bank Terhadap Rasio Non-Performing Financing (NPF)}

Analisis Pengaruh BI Rate Terhadap Non-Performing Financing pada BPRS di Indonesia menunjukkan bahwa BI berpengaruh positif dan signifikan dan memiliki nilai koefisien positif terhadap NPF pada BPRS di Indonesia. BI Rate atau suku Bunga bank Indonesia merupakan bunga yang ditetapkan oleh bank sentral yang mencerminkan sikap kebijakan moneter yang diumumkan kepada masyatakat umum, dalam hal ini ialah Bank Indonesia selaku bank sentral di Indonesia. Hubungan positif dan signifikan antara BI rate dan NPF dikarenakan perbankan di Indonesia masih menggunakan dual banking system yaitu bank konvensional dan bank syariah. Suku bunga kredit bank umum akan meningkat apabila BI Rate mengalami kenaikan, sehingga dapat berpengaruh terhadap pembiayaan pada bank yaitu meningkatnya pembiayaan bermasalah.

Ketidakmampuan nasabah dalam memenuhi kewajibannya disebabkan tingginya beban bunga yang ditanggung. Walaupun perbankan syariah tidak mengenal sistem bunga dalam menjalankan operasionalnya, namun secara tidak langsung kenaikan BI Rate dijadikan benchmark oleh bank syariah, selain itu baik bank syariah maupun konvesional tidak dapat menghindari persaingan di industri perbankan sebagai sesama lembaga bisnis. Tingkat persaingan antara kedua sistem bank menjadikan kebijakan yang diambil salah satu pihak akan mempengaruhi perbankan yang lain. Dalam hal ini ketika terjadi kenaikan suku bunga BI maka nasabah yang ingin mengajukan pembiayaan di bank konvensional akan beralih ke bank syariah karena tingginya suku bunga di bank konvensional. Hal ini akan menyebabkan pembiayaan di bank syariah akan semakin tinggi dan berpengaruh terhadap rasio NPF yang semakin besar. Begitu juga sebaliknya ketika BI Rate turun, maka perbankan konvesional juga akan menurunkan tingkat suku bunganya, sehingga margin bagi hasil pada BPRS sebagai perbankan Syariah juga akan kompetitif dan akan mengurangi pembiayaan bermasalah pada BPRS itu sendiri. Hasil ini sesuai dengan penelitian yang dilakukan oleh Stract \& Uluan (2016).

Berdasarkan hasil pengolaha data variabel PDRB memiliki pengaruh positif terhadap NPF pada BPRS di Indonesia. PDRB dapat mencerminkan pertumbuhan ekonomi suatu daerah. Semakin tinggi tingkat PDRB pada suatu wilayah maka menandakan bahwa perekonomian pada daerah tersebut dalam kondisi baik, jika dikaitkan dengan pembiayaan maka masyarakat dalam hal ini sebagai nasabah mampu membayar kewajibannya terhadap bank sehingga tingkat pembiayaan bermasalah menjadi menurun. Hal ini sesuai dengan penelitian yang dilakukan oleh Effendi et al. (2017), Umar \& Gang Sun (2018) dan Firdaus (2015) dimana dalam penelitianya menemukan bahwa GDP memiliki pengaruh positif terhadap NPF pada perbanakan syariah. Menurutnya saat ekonomi tumbuh, maka pendapatan yang dihasilkan dari sektor perusahaan maupun non perusahaan juga meningkat dan mereka dapat membayar pinjaman pada perbankan, sehingga menurutnya hal tersebut menjadi kontribusi terhadap menurunya rasio pembiayaan bermasalah.

Sementara itu variabel inflasi dan pengangguran tidak memiliki pengaruh terhadap NPF pada BPRS di Indonesia. Inflasi merupakan kenaikan harga - harga barang secara umum dan terus menerus yang disebabkan karena jumlah uang yang lebih banyak dibandingkan dengan jumlah barang dan jasa yang ditawarkan. Inflasi terjadi karena pertumbuhan jumlah uang tersebut melebihi pertumbuhan sektor riil sehingga daya beli masyarakat menjadi turun. Maka dari itu dapat dikatakan inflasi mempengaruhi kegiatan perekonomian dalam suatu negara baik secara makro maupun mikro. Dari hasil pengujian menunjukkan inflasi tidak berpengaruh signifikan terhadap NPF. Hal ini sesuai dengan penelitian yang dilakukan oleh Asnaini (2014) yang menyatakan bahawa variabel inflasi tidak memiliki pengaruh yang signifikan terhadap NPF pada perbankan syariah di Indonesia. Hal tersebut dikarenakan pada BPRS tingginya tingkat inflasi tidak membuat nasabah mengesampingkan kewajibannya dalam melunasi pinjamannya, selain itu menurutnya BPRS lebih banyak bermain pada sektor mikro sehingga memiliki ketahanan yang lebih kuat terhadap perlambatan ekonomi, sehingga perubahan keadaan ekonomi seperti naik turunya inflasi tidak berdanpak pada BPRS.

Sementara itu, pengangguran tidak berpengaruh signifikan terhadap NPF pada BPRS di Indonesia. Hal ini tidak sesuai dengan hipotesis awal dan juga teori yang ada dimana ketika pengangguran tinggi maka akan diikuti dengan tingginya nilai pembiayaan bermasalah karena ketika pengangguran tinggi maka perekonomian dalam kondisi yang tidak baik. Namun dari hasil penelitian ini ditemukan hasil bahwa tingkat pengangguran justru tidak memiliki pengaruh terhadap tingkat pembiayaan bermasalah pada BPRS yang ada di Indonesia. Hal ini diduga karena pengangguran tidak berpengaruh secara langsung terhadap pembiayaan bermasalah mengingat obyek dari pembiayaan BPRS adalah UMKM yang merupakan pekerja mandiri. 


\section{Kesimpulan}

Berdasarkan hasil penelitian di atas dapat disimpulkan bahwa variabel total asset dan CAR/KPPM berpengaruh negatif terhadap NPF. Hal ini menunjukkan bahwa ketika rasio kewajiban penyediaan modal minimum semakin meningkat maka NPF akan menurun. Di lain pihak BOPO berpengaruh positif terhadap NPF. Upaya BPRS dalam menekan biaya operasionalnya dan menambah pendapatan operasionalnya akan menghasilkan rasio BOPO yang kecil sehingga hal tersebut juga akan menurunkan tingkat pembiayaan yang ada pada BPRS. Dimana pada saat BPRS memiliki pendapatan yang banyak, maka itu berarti tingkat kredit macet sangatlah rendah. Sementara itu, ROA berpengaruh negatif terhadap NPF. Sedangkan BI Rate dan PDRB berpengaruh positif terhadap NPF. Sementara itu inflasi dan pengangguran tidak memiliki pengaruh signifikan terhadap NPF.

Dari hasil pengujian dan analisis pembahaan yang telah dilakukan, maka peneliti memberikan rekomendasi yaitu dalam rangka menanggulangi kradit bermasalah maka BPRS harus memperbaiki kondisi keuangan internal serta peka terhadap kondisi makroekonomi. Kondisi keuangan internal salah satunya adalah dengan memperkuat permodalan mengingat peran modal sangat penting untuk menjaga kepercayaan masyarakat dan modal juga berperan untuk menyangga risiko. BPRS setidaknya harus memenuhi rasio KPMM yang telah ditetapkan oleh regulator sebagai pondasi awal untuk membangun kepercayaan dari masyarakat. Disamping memperbaiki kondisi internal, BPRS juga harus peka terhadap kondisi makroekonomi. Hal ini penting karena kinerja BPRS ditentukan oleh kondisi ekonomi wilayah dimana bank beroperasi. Bank yang berada di wilayah dengan tingkat persaingan tinggi dan kondisi ekonomi daerah yang baik kinerjanya tentu akan berbeda dengan bank yang berada di wilayah dengan tingkat persaingan rendah dan kondisi ekonomi rendah

\section{Daftar Pustaka}

Asnaini, S. W. (2014). Fakor-faktor yang mempengaruhi non performing financing (NPF). Jurnal Telaah Akuntansi Dan Bisnis, 5 (02), 264-280.

Effendi, J., Thiarany, U., \& Nursyamsiah, T. (2017). Factors influencing non performing financing ( NPF ) at Sharia Banking. Jurnal Penelitian Sosial Keagamaan, 25(1), 109-138. https://doi.org/10.21580/ws.25.1.1540

Firdaus, R. N. (2015). Pengaruh faktor internal dan eksternal yang mempengaruhi pembiayaan bermasalah pada bank umum syariah di Indonesia. Jurnal El Dinar, 3(1), 82-108

Firmansyah, I. (2014). Determinant of non performing loan: the case of Islamic Bank in Indonesia. Buletin Ekonomi Moneter dan Perbankan, 17(2), 241-258.

Joseph, M. T., Edson, G., Manuere, F., Clifford, M., Michael, K., \& Kamoyo, M. (2012). Non performing loans in commercial banks: a case of CBZ Bank Limited in Zimbabwe. Interdisciplinary Journal of Contemporary Research in Business, 4(7), 467-488.

Kusmayadi, D., Firmansyah, I., \& Badruzaman, J. (2017). The impact of macroeconomic on non performing loan : comparison study at conventional and syariah banking. Jurnal Kajian Ekonomi dan Bisnis Islam, 10, 59 82. https://doi.org/10.21043/iqtishadia.v10i2.2864

Mutamimah, \& Chasanah, S. N. Z. (2012). Analisis eksternal dan internal dalam menentukan NPF. Jurnal Bisnis dan Ekonomi, 19(1), 49-64.

Negara, W. (2012). Determinants of non performing loans the case of Ethiopian banks. A Research Report, South Africa: University of South Africa. https://core.ac.uk/download/pdf/43168979.pdf

Otoritas Jasa Keuangan. (2017). Laporan kinerja OJK 2012-2017. Jakarta: OJK https://www.ojk.go.id/id/data-danstatistik/laporan-kinerja/Documents/Laporan\%20Capaian\%20Kinerja\%20OJK\%202012\%20\%202017.pdf

Sholihatun, N., \& Sriyana, J. (2014). Profitabilitas bank syariah pada kondisi biaya operasional tinggi. Prosiding Seminar Nasional, Penelitian Ekonomi, Bisnis dan Keuangan Pemberdayaan Perekonominan Nasional (1-20). https://anzdoc.com/profitabilitas-bank-syariah-pada-kondisi-biaya-operasional-t.html

Stract, A. B., \& Uluan, P. E. (2016). Dampak inflasi , BI rate, capital adequacy ratio (CAR), biaya operasional pendapatan operasional (BOPO) terhadap non performing financing (NPF) pada bank. Journal of Islamic Finance, 2(1), 1-19.

Umar, M., \& Sunm G. (2018). Determinants of non-performing loans in Chinese banks. Journal of Asia Business Studies, 12(3), 273-289. 